\title{
Arundo donax L. (Giant reed) Use by Turkish Cypriots
}

Salih Gücel

\section{Research}

\section{Abstract}

A survey about the traditional uses of Arundo donax L. (Giant reed) by Turkish Cypriots was carried out. Sixty inhabitants from 25 areas were interviewed about the vernacular names, plant part used and forms of usage. Twenty-seven ways of utilizing this plant were recorded. The ethnobotanical importance of Arundo should be considered in the management of this plant.

\section{Introduction}

"Utility of a plant to humans is related to: (1) abundance and distribution of the plant; (2) length of time the plant and a human group have been in contact; (3) invention or transmission of traditional ecological knowledge of the taxon; (4) ease of managing, acquiring, and processing the plant; (5) physical and chemical qualities of the plant (e.g., pharmaceutical or toxicological properties, fiber characteristics, nutritional composition); and (6) availability and quality of alternate taxa." (Kiviat \& Hamilton 2001)

About twelve species belonging to the genus Arundo are widely distributed in tropical and warm-temperate regions (Meikle 1985). One of these, Arundo donax L., is considered indigenous to the Mediterranean Basin (Hickman 1993, TNC 1996) and to warmer regions of the Old World (Munz \& Keck, 1959, Robbins et al. 1951). It is found in low gradient river courses and may provide useful wildlife habitat in greatly altered river deltas (Granval et al. 1993, He et al. 1991).

This species has played an important role in the culture of the western world through its influence on the development of music, which can be traced back 5000 years. The basis for the origin of the most primitive pipe organ, the Pan pipe or syrinx, was made from $A$. donax. Reeds for woodwind musical instruments are still made from the culms and no satisfactory substitutes have been developed (Merzouki et al. 2000, Perdue 1958). Even before its musical qualities were appreciated, Egyptians used $A$. donax to line the floor and walls of underground grain stores. Mummies of the fourth century A.D. were wrapped in Arundo leaves. Other uses for $A$. donax include basket-work, garden fences and trellises, chicken pens, crude shelters, fishing rods, arrows, erosion control, livestock fodder, pulp and ornamental plants, also the culm is used in building a structural support for grape vines. The leaves were used as stuffing for pillows or mattresses. The culm and rhizomes are still used for walking sticks and the woven culm was used to build a "poor man's" grain bin (Pieroni \& Quave 2006). Medicinally, the rhizome has been used as a sudorific, a diuretic, an antigalactagogue and in the treatment of dropsy (Perdue 1958) and the white hemicellulose membrane (located at the nodes) of the stem, are used to stuff wounds as a haemostatic and also to treat herpes outbreaks on the lips (Pieroni \& Quave 2006).

\section{Correspondence}

Salih Gücel, Yakın Doğu Üniversitesi / Near East University, Çevre Bilimleri Enstitüsü / Institute of Environmental Sciences, Nicosia, North Cyprus. sgucel@hotmail.com

Ethnobotany Research \& Applications 8:245-248 (2010)

Published: August 29, 2010 
Arundo donax was brought to North America where it became abundant by 1820 in the Los Angeles River, where it was harvested for roofing material and fodder (Robbins et al. 1951). Commercial plantations exist in California based on cane use for musical instrument production. Horticultural propagation is widely conducted, and varieties of $\mathrm{Ar}$ undo are available and commonly used in gardens or for erosion control (Brenzel 1967, Loewer 1995).

Arundo donax is the only species of Arundo found in Cyprus. It is widespread and locally abundant in the northwestern part of the island, around riverbeds and lakes. It was grown especially around citrus groves as a shelter for wind, in order to protect flowers. This way of usage increased its availability and locals used it to produce equipment for their daily lives. A literature review on the uses of $A$. donax by Turkish Cypriots revealed that there was a lack of information on this subject. Some uses of Arundo (matting, basketry, etc.) are similar to uses of Phragmites spp. and Typha spp., whereas other uses (shelter for wind, roofing) are related to the special qualities of $\mathrm{Ar}$ undo which are rarely found in other robust graminoids. It became obvious that $A$. donax was confused with Typha and Phragmites and vernacular names of different uses of A. donax were applied to Typha and Phragmites and vice versa. Therefore, in this paper we investigated the use of A. donax by Turkish Cypriots.

\section{Materials and Methods}

Sixty subjects, 30 males and 30 females, belonging to 5 age groups (10-18, 19-35, 36-50 and 50+) from 25 areas were interviewed about the vernacular names, plant part used and ways of usage in the Turkish Cypriot community in the northern part of Cyprus. In order to reduce errors, the interviews were conducted with the aid of plant samples.

Collection of the information started from the local markets, where the products were sold. Then we interviewed the producers at their villages or towns. During the interviews, they were asked to provide information about the types of usage of $A$. donax and to recommend other subjects to be interviewed.

\section{Results}

Our results showed that $A$. donax is widely used and with greater diversity of uses in the northwest of Cyprus. A total of 27 types of uses were recorded (Table 1.). All plant

Table 1. Uses of Arundo donax L. reported from interviews with Turkish Cypriots in northwest Cyprus.

\begin{tabular}{|l|l|l|l|l|}
\hline \multirow{2}{*}{ Use } & $\begin{array}{l}\text { Turkish Cypriot } \\
\text { Name }\end{array}$ & Plant Part & Frequency & $\begin{array}{l}\text { Age groups } \\
\text { of subjects }\end{array}$ \\
\hline \multirow{2}{*}{ Baskets } & Sepet & Culm & $100 \%$ & All \\
\cline { 2 - 5 } & Köfün & & & \\
\hline Candy bowl & Yemişlik & Culm & $100 \%$ & All \\
\hline Chandelier & Avize & Culm & $100 \%$ & All \\
\hline Fruit/Vegetable bowl & Sebzelik/Meyvelik & Culm & $100 \%$ & All \\
\hline Mat & Hasır & Culm & $100 \%$ & All \\
\hline Support for climbing plants & Sarılıcı bitkilere \\
& destek & Culm & $100 \%$ & All \\
\hline Table & Masa & Culm & $100 \%$ & All \\
\hline Fishing equipment & Olta & Culm & $80 \%$ & All \\
\hline Fence & Çit & Culm & $70 \%$ & All \\
\hline Laundry basket & Çamaşır sepeti & Culm & $70 \%$ & All \\
\hline Musical instruments & Dilli düdük & Culm & $60 \%$ & All \\
\hline Knife & Tarhana bıçağı & Culm & $40 \%$ & $19<$ \\
\hline Roofing & Çatı materyali & Culm & $40 \%$ & All \\
\hline Shelter construction (for sun) & Galif & Above ground parts & $40 \%$ & $19<$ \\
\hline Shelter construction (for wind) & Rüzgar koruması & Whole plant & $30 \%$ & $19<$ \\
\hline Distaff & Kecefe & Culm & $20 \%$ & $35<$ \\
\hline Heddle & Tezgah tarağı & Culm & $20 \%$ & $35<$ \\
\hline Stick to unspun thread & Ilgıdır & Culm & $20 \%$ & $35<$ \\
\hline Weaving rod, spool & Gelemgen & Culm & $20 \%$ & $35<$ \\
\hline
\end{tabular}




\begin{tabular}{|l|l|l|l|l|}
\hline Use & $\begin{array}{l}\text { Turkish Cypriot } \\
\text { Name }\end{array}$ & Plant Part & Frequency & $\begin{array}{l}\text { Age groups } \\
\text { of subjects }\end{array}$ \\
\hline Bread or Cheese basket and a cover & Tabaca & Culm & $10 \%$ & $35<$ \\
\hline Chicken coop for transport & Köfe & Culm & $10 \%$ & $35<$ \\
\hline Door covering & Kapı perdesi & Culm & $10 \%$ & $50+$ \\
\hline Protective cover & Iriza & Culm & $10 \%$ & $35<$ \\
\hline Container for kohl & Sürmelik & Culm & $5 \%$ & $50+$ \\
\hline Toy (squirt gun) & Fitsigla & Culm & $5 \%$ & $50+$ \\
\cline { 1 - 2 } (kite) & Uçurgan, Uçurtma & & & \\
\hline
\end{tabular}

parts are used, with the culm being the most important. The use of $A$. donax was more popular among the older generation.

The plant was grown especially around citrus groves as a shelter for wind. Another use was to place the green, above-ground parts on top of a shelter and to secure them with ropes to produce shade. Moreover, when the culm was the main material, it was used when it was wet, and easy to shape. It was used as a whole or divided horizontally into two or three equal parts according to its diameter.

\section{Discussion}

The importance of a plant species to a society may be assessed by the development of culture associated with collection and processing, as well as by the diversity of uses. The technological importance of Arundo in non-industrial settings is related to the characteristics of the plant, especially, the culms, which are strong, hollow, lightweight, buoyant, rapidly growing and durable. These characteristics, and hence many of its uses, are unusual for an herbaceous plant.

The use of $A$. donax in Cyprus is declining, due to two main reasons. The first one is the rapidly changing lifestyles with the development of technology as a result of which people use technological materials instead of traditional ones. As an example of this, we found that the younger generation, from 40 years old and younger, is not aware of half of the methods.

The second reason is the reduction in the availability of Arundo. The need for Arundo as a wind screen to protect flowers from wind and increase fruit yield, is decreasing as a result of the replacement of orange orchards into less water demanding crops (Iverson 1994, Perdue 1958).

We found that women and men had the same level of knowledge about traditional uses while in villages subjects were more aware than in towns. This is probably because most subjects in the villages were over 40 years old who still use traditional materials which are less costly.
Conservation strategies to protect this species should also promote the production and sale of traditional household utensils and equipment to tourists as an example of the island's culture.

\section{Acknowledgements}

I would like to thank the Environmental Protection Office and am grateful to Mustafa Kemal Meraklı for his assistance. Also I would like to thank the three anonymous referees for their valuable comments which helped to improve the final manuscript.

\section{Literature Cited}

Brenzel, K.N. 1967. Sunset Western Garden Book. Lane Books, Menlo Park, California.

Merzouki, A., F. Ed-Derfoufi \& J.M. Mesa. 2000. Contribution to the knowledge of Rifiarian traditional medicine. II Folk medicine in Ksar Lakbir District (NW Morocco). Fitoterapia 71:278-307.

Granval, P., R. Aliaga \& P. Soto. 1993. The impact of agricultural management on earthworms (Lumbricidae), common snipe (Gallinago gallinago) and the environmental value of grasslands in the Dives marshes (Calvados). Gibier Faune Sauvage 10:59-73.

He, X., X. Yang \& T. Li. 1991. A preliminary study in the ecology of the lesser bamboo rat (Cannomys badius) in China. Zoological Research 12:41-46.

Hickman, J.C. 1993. Editor of The Jepson Manual: Higher plants of California. University of California Press, Berkeley, California.

Iverson, M.E. 1994. The impact of Arundo donax on water resources. Pp. 19-25 in Arundo donax Workshop in November 1993. Edited by N.E. Jackson, P. Frandsen \& S. Douthit. Ontario, California.

Kiviat, E. \& E. Hamilton. 2001. Phragmites use by Native North Americans. Aquatic Botany 69(2-4):341-357. 
Loewer, P. 1995. Step-by-Step Successful Gardening: Ornamental grasses. Better Homes \& Gardens Books, Des Moines, lowa.

Meikle, R.D. 1985. Flora of Cyprus. Vol.II. Bentham-Moxon Trust, London, Royal Botanic Gardens, Kew.

Munz, P.A. \& D.D. Keck. 1959. A California Flora. In collaboration with D.D. Keck. University of California Press, Berkeley, California.

Perdue, R.E. 1958. Arundo donax - source of musical reeds and industrial cellulose. Economic Botany 12:368404.
Pieroni, A. \& C.L. Quave. 2006. Functional foods or foodmedicines? On the consumption of wild plants among Albanians and Southern Italians in Lucania. Pp. 101-129 in Eating and Healing: Traditional food as medicine. Edited by A. Pieroni \& L.L. Price. Haworth Press, Binghamton.

Robbins, W.W., M.K. Bellue \& W.S. Ball. 1951. Weeds of California. California Department of Agriculture, Sacramento.

TNC. 1996. Control and Management of Giant reed (Arundo donax) and Saltcedar (Tamarix spp.) in Waters of the United States and Wetlands. Report by The Nature Conservancy, Southern California Projects Office, to US Army Corps of Engineers, Los Angeles. 